\title{
Melanoides tuberculata (MOLLUSCA: THIARIDAE) AS AN INTERMEDIATE HOST OF Centrocestus formosanus (TREMATODA: HETEROPHYIDAE) IN BRAZIL
}

\author{
Hudson Alves PINTO \& Alan Lane de MELO*
}

\begin{abstract}
SUMMARY
Pleurolophocercous cercariae emerged from naturally infected Melanoides tuberculata from Minas Gerais State, Brazil, were used to perform experimental infection of laboratory-reared Poecilia reticulata. Mature metacercariae were obtained from the gills of fishes and force-fed to Mus musculus. The adult parasites which recovered from small intestines of mice were identified as Centrocestus formosanus. This is the first report of M. tuberculata as intermediate host of this heterophyid in Brazil.
\end{abstract}

KEYWORDS: Centrocestus formosanus; Melanoides tuberculata; Brazil; Experimental infection; Trematoda.

Melanoides tuberculata (Müller, 1774), an exotic mollusc introduced in Brazil in the late $1960 \mathrm{~s}^{40}$, has been found in several states in Brazil ${ }^{12}$. Despite some studies related to the interaction between $M$. tuberculata and planorbid molluscs which transmit Schistosoma mansoni Sambon, 1907 in the country ${ }^{13,14}$, the possible damage on the native fauna as alien species and their potential to act as parasite vector in the country have not yet been evaluated. In this later aspect, some studies had already reported the finding of $M$. tuberculata harboring pleurolophocercous cercariae in Brazil $^{5,6,39}$, but these larvae, characterized as Pleurolophocercous type, still remain without a specific identification.

In the present study, malacological surveys were performed at Pampulha dam (an artificial lake located between $43^{\circ} 58^{\prime}$ and $44^{\circ} 01^{\prime} \mathrm{W}$ and $19^{\circ} 50^{\prime}$ and $19^{\circ} 52^{\prime} \mathrm{S}$, in the northern region of the city of Belo Horizonte and $2 \mathrm{~km}$ away from the campus of "Universidade Federal de Minas Gerais") from March 2006 to July 2009. Molluscs were collected with a scoop net and long forceps. After a preliminary trial, molluscs were placed in a thermal box, labeled and shipped to the laboratory. Then they were placed individually in plastic recipients containing $5 \mathrm{~mL}$ of tap water and left overnight at room temperature. Thiarids were examined with a stereomicroscope before and after artificial photostimulation for two hours. Emerged larvae were collected with micropipette, transferred to glass slides and analyzed with vital stains $(0.05 \%$ neutral red, $0.05 \%$ toluidine blue, $0.05 \%$ alizarin red) or fixed and then stained with acetic carmine and mounted in Canada balsam ${ }^{23}$.

Cercariae were concentrated by filtration using a Buchner funnel ${ }^{31}$ and one hundred larvae in $5 \mathrm{~mL}$ were used for individual infection of 30 adult specimens (2-3 cm of length) of laboratory reared Poecilia reticulata Peters, 1859 (Pisces: Poeciliidae). Thirty days after infection the surviving fishes were necropsied in order to recover metacercariae. Cysts obtained from gills of experimentally infected fish were administered per os to five mice of the AKR/J strain. Fifteen days after infection, mice were sacrificed by cervical dislocation according to the local animal experimentation ethics committee (CETEA/UFMG), and their intestines were thoroughly and longitudinally opened in Petri dishes containing $0.85 \%$ saline solution and adult parasites were recovered from the proximal third of the small intestine. Parasites were studied alive or then placed between the slide and the coverslip with slight pressure, fixed in cold $10 \%$ formalin, stained with acetic carmine, dehydrated, cleared in benchwood and mounted in Canada balsam.

Drawings were made using a camera lucida and specimens were measured with a millimitered eyepiece. Photographic documentation was performed in light microscope. The results were compared with taxonomical keys ${ }^{7}$ and morphological descriptions from several authors ${ }^{3,9,10,17,18,22,29}$. The specimens studied were deposited at the collection of Department of Parasitology (DPIC), UFMG.

From 3,834 specimens of M. tuberculata collected, $268(7.0 \%)$ were naturally infected by larval trematodes preliminarily characterized as belonging to the group of Pleurolophocercous cercariae. These larvae encysted in $P$. reticulata and out of thirty fish experimentally infected, twenty survivors were analyzed, all of them presenting viable metacercariae which were used for inoculation of mice. Fifty ovigerous worms with 32 circumoral spines were obtained from the experimentally infected mice and identified as members of family Heterophyidae Leiper, 1909, subfamily Centrocestinae Looss, 1899 and the species Centrocestus formosanus (Nishigori, 1924) (Fig. 1). The morphology and morphometry of the developmental stages obtained are in accordance with the original

\footnotetext{
* Laboratório de Taxonomia e Biologia de Invertebrados, Departamento de Parasitologia, Instituto de Ciências Biológicas, UFMG, Belo Horizonte, MG, Brasil.

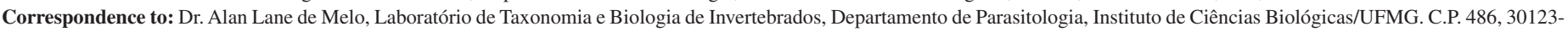
970 Belo Horizonte, Minas Gerais, Brasil. E-mail: aldemelo@icb.ufmg.br
} 


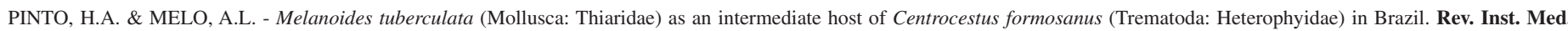
Trop. Sao Paulo, 52(4): 207-10, 2010.

description and with experimental studies conducted by different authors (Table 1). Measurements are presented by the mean followed by the range in parenthesis.

C. formosanus was described in 1924 from adult parasites recovered from natural and experimental definitive hosts in Taiwan ${ }^{29}$. The life cycle of this trematode was also studied in China, where M. tuberculata were recognized as the first intermediate hosts and fishes and frogs as second intermediate hosts ${ }^{9,10}$. The species was introduced in the New World in the late $1950 \mathrm{~s}^{22}$, possibly by thiarids, migratory birds and/or exotic fishes naturally infected.

Among fish, several species of different families have already been reported as naturally and experimentally infected in many countries. The development of metacercariae on gills causes pathological changes which, in some cases, as high parasite burden, may cause the death of these hosts and damage in aquaculture ${ }^{2,15,24,25,26,28,30,35,36,42}$.

Adult parasites, in turn, have already been reported naturally in fish-eating birds (Butorides striatus (Linnaeus, 1758); Bubulcus ibis coromandus (Boddaert, 1783) and Nycticorax nycticorax (Linnaeus, 1758)), and mammals, including human beings ${ }^{9,11,19,20,21,28,29,32,44}$.

Several experimental models, among birds (chickens, ducks, pigeons) and mammals (dogs, cats, Rhesus monkeys, mice, hamsters, rats and rabbits), were found to be susceptible to infection with the trematode in

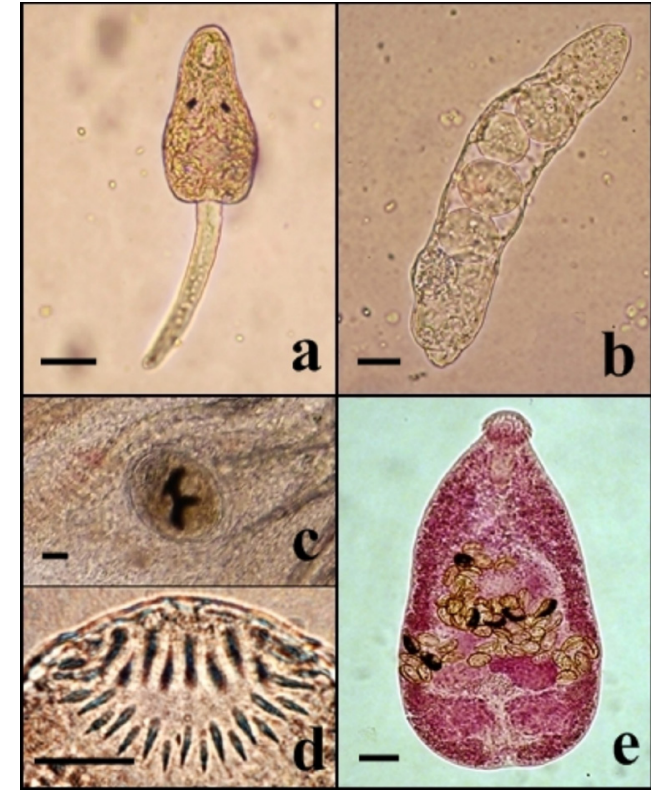

Fig. 1 - Developmental stages of Centrocestus formosanus: (a) A cercaria and (b) a redia from naturally infected $M$. tuberculata collected at Pampulha Dam, Belo Horizonte, Minas Gerais, Brazil. (c) A metacercaria from experimentally infected Poecilia reticulata. (d) Oral sucker of an adult worm showing circumoral spines and (e) entire body of an adult parasite recovered from an experimentally infected mice. Bars $=50 \mu \mathrm{m}$.

Table 1

Morphometric comparison between adult parasites of Centrocestus formosanus experimentally obtained in the present study and those reported by other authors. Means of measurements (in $\mu \mathrm{m}$ ) followed by the range in parenthesis

\begin{tabular}{|c|c|c|c|c|c|c|c|c|}
\hline Source & & Present study & Nishigori, 1924 & Chen, 1942 & $\begin{array}{c}\text { Arizmendi- } \\
\text { Espinosa, } 1992\end{array}$ & $\begin{array}{l}\text { Hernandez et al., } \\
2003\end{array}$ & $\begin{array}{l}\text { Velasquez et al., } \\
2006\end{array}$ & Han et al., 2008 \\
\hline Locality & & Brazil & Taiwan & Hong Kong & Mexico & Venezuela & Colombia & Laos \\
\hline Host & & Mus musculus & $\begin{array}{l}\text { Nycticorax } \\
\text { nycticorax }\end{array}$ & Rattus rattus & Gallus gallus & Rattus rattus & Gallus gallus & Mus musculus \\
\hline$\underline{\text { Parasites }}$ & $\mathrm{N}$ & 15 & - & 20 & 10 & - & 24 & 10 \\
\hline \multirow[t]{2}{*}{ Body } & $\mathrm{L}$ & $322(232-479)$ & 362 & $461(314-572)$ & $248(240-326)$ & $232-469$ & $370(350-370)$ & $286(245-325)$ \\
\hline & W & $214(184-279)$ & 197 & $212(171-242)$ & $119(101-146)$ & $106-237$ & $136(125-150)$ & $192(155-220)$ \\
\hline \multirow[t]{2}{*}{ Oral sucker } & $\mathrm{L}$ & $58(47-67)$ & 50 & 60 & $32(30-37)$ & $29-67$ & $46(37-53) d$ & $52(45-58)$ \\
\hline & W & $44(33-49)$ & 47 & 56 & $40(33-48)$ & $32-61$ & - & $43(38-50)$ \\
\hline Spines & $\mathrm{N}$ & 32 & 32 & $30-36$ & 32 & 32 & 32 & $32(32-34)$ \\
\hline \multirow[t]{2}{*}{ Pharynx } & $\mathrm{L}$ & $30(27-36)$ & $40-47$ & 41 & $30(22-37)$ & $26-40$ & 27 & $32(28-34)$ \\
\hline & W & $21(16-24)$ & $20-35$ & 42 & $22(18-30)$ & $21-37$ & 23 & $26(20-30)$ \\
\hline \multirow[t]{2}{*}{ Ventral sucker } & $\mathrm{L}$ & $54(44-60)$ & $36-43$ & 52 & $34(30-41)$ & $26-53$ & $37(33-38)$ & $48(45-55)$ \\
\hline & W & $48(41-55)$ & $39-55$ & 55 & $40(33-48)$ & $32-61$ & $33(31-35)$ & $35(33-45)$ \\
\hline \multirow[t]{2}{*}{ Right testis } & $\mathrm{L}$ & $46(33-55)$ & 43 & 71 & $34(26-48)$ & $29-67$ & $53 \mathrm{~d}$ & $38(24-50)$ \\
\hline & $\mathrm{W}$ & 77 (63-93) & 89 & 106 & $32(22-56)$ & $40-94$ & - & 65 (45-93) \\
\hline \multirow[t]{2}{*}{ Left testis } & $\mathrm{L}$ & $43(36-60)$ & 42 & 74 & $35(20-48)$ & $26-59$ & $48 \mathrm{~d}$ & $40(30-63)$ \\
\hline & W & $77(65-91)$ & 78 & 101 & $39(26-56)$ & $51-96$ & - & $66(55-88)$ \\
\hline \multirow[t]{2}{*}{ Ovary } & $\mathrm{L}$ & $45(40-52)$ & 54 & 67 & $30(22-45)$ & $32-80$ & - & $42(34-46)$ \\
\hline & W & $83(67-101)$ & 40 & 83 & $34(22-45)$ & $34-110$ & - & $60(50-80)$ \\
\hline \multirow[t]{3}{*}{ Eggs } & $\mathrm{L}$ & $35(32-37)$ & 33 & $34(32-39)$ & $28(22-33)$ & $21-40$ & 35 (24-39) & $34(30-36)$ \\
\hline & W & $18(16-20)$ & 17 & $19(17-20)$ & $17(15-22)$ & $14-18$ & $19(15-23)$ & $17(15-19)$ \\
\hline & $\mathrm{N}^{*}$ & $21(5-55)$ & $10-45$ & \pm 20 & - & - & - & $10(4-16)$ \\
\hline
\end{tabular}

L: length, W: width, $\mathrm{N}$ : number, d: diameter; * number of intrauterine eggs. 


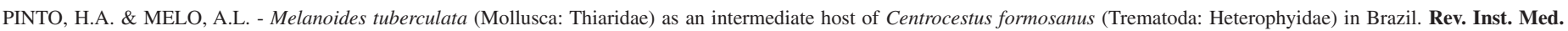
Trop. Sao Paulo, 52(4): 207-10, 2010.

several parts of the world $3,9,18,22,27,28,34,38$, being considered a parasite with low intraspecific variability among different hosts and places ${ }^{36}$.

In the American continent there are some published reports of the parasite in the USA ${ }^{22,24,25,26}$, Mexico ${ }^{1,3,36}$, Venezuela ${ }^{18}$, Colombia ${ }^{41,43}$. Recently the occurrence of C. formosanus in Poecilia vivipara (Bloch \& Schneider, 1801), from Rio de Janeiro, Brazil was reported in a congress communication $^{37}$. However, until the present study the intermediate host of this heterophid was unknown in this country.

In Minas Gerais State, M. tuberculata was introduced in the 1980's reaching a high population density one decade after the first report ${ }^{4}$ and today is considered to be a well established population. Due to the existence of several species of piscivorous birds, resident and visiting ones $^{33}$, as well as a rich ichthyofauna ${ }^{16}$, the Pampulha dam has become an appropriate environment to maintain the life cycle of $C$. formosanus.

The control strategy against the spread of this trematode and the intermediate host, $M$. tuberculata, need to be implemented to prevent the spread of human and veterinary cases of this parasite in Brazil. This is the first report of $C$. formosanus in M. tuberculata from Brazil and of this Heterophyidae in the state of Minas Gerais.

\section{RESUMO}

\section{Melanoides tuberculata (Mollusca: Thiaridae) como hospedeiro intermediário de Centrocestus formosanus (Trematoda: Heterophyidae) no Brasil}

Cercárias do tipo pleurolofocerca emergidas de Melanoides tuberculata naturalmente infectados coletados na represa da Pampulha, Belo Horizonte, Minas Gerais, Brasil, foram utilizadas para a infecção experimental de Poecilia reticulata criados em laboratório. Metacercárias maduras foram obtidas nas brânquias dos peixes e administradas por via oral a Mus musculus. Parasitos adultos recuperados no intestino delgado dos camundongos foram identificados como Centrocestus formosanus. Este é o primeiro relato de $M$. tuberculata como hospedeiro intermediário deste parasito no Brasil.

\section{ACKNOWLEGMENTS}

To Mr. Airton Lobo for technical assistance and to the Conselho Nacional de Desenvolvimento Científico e Tecnológico (CNPq) for financial support and scholarship to H.A.P.

\section{REFERENCES}

1. Aguilar-Aguilar R, Martínez-Aquino A, Pérez-Rodríguez R, Pérez-Ponce de León G. Digenea, Heterophyidae, Centrocestus formosanus (Nishigori, 1924) metacercariae: distribution extension for Mexico, new state record, and geographic distribution map. Check List. 2009;5:357-9.

2. Alcaraz G, Pérez-Ponce de Leon G, García-Prieto L, León-Règagnon V, Vanegas C. Respiratory responses of grass carp Ctenopharyngodon idella (Cyprinidae) to parasitic infection by Centrocestus formosanus (Digenea). Southwest Nat. 1999;44:222-6.

3. Arizmendi-Espinosa MA. Descripción de algunas etapas larvarias y de la fase adulta de Centrocestus formosanus de Tezontepec de Aldama, Hidalgo. An Inst Biol Univ Nac Auton Mex Ser Zool. 1992;63:1-11.
4. Bedê LC. Dinâmica populacional de Melanoides tuberculata (Prosobranchia: Thiaridae) no reservatório da Pampulha, Belo Horizonte, MG, Brasil [Dissertação] Belo Horizonte: Instituto de Ciências Biológicas da Universidade Federal de Minas Gerais; 1992.

5. Boaventura MF, Fernandez MA, Thiengo SC, Silva RE, Melo AL. Formas larvais de Trematoda provenientes de gastrópodes límnicos da microrregião Rio de Janeiro, sudeste do Brasil. Lundiana. 2002;3:45-9.

6. Bogéa T, Cordeiro FM, Gouveia JS. Melanoides tuberculatus (Gastropoda: Thiaridae) as intermediate host of Heterophyidae (Trematoda: Digenea) in Rio de Janeiro metropolitan area, Brazil. Rev Inst Med Trop Sao Paulo. 2005;47:87-90.

7. Bray RA, Gibson D, Jones A. Keys to the Trematoda. London: CAB International and Natural History Museum; 2008. v. 3.

8. Carvalho OS. Ocorrência de um tiarídeo (Mollusca) no lago da Pampulha, Belo Horizonte, MG, Brasil. Rev Soc Bras Med Trop. 1986;19:57-9

9. Chen HT. The metacercaria and adult of Centrocestus formosanus (Nishigori, 1924) with notes on the natural infection of rats and cats with C. armatus (Tanabe, 1922). J Parasitol. 1942;28:285-98.

10. Chen HT. Some early larval stages of Centrocestus formosanus (Nishigori, 1924) Lingnan Sci J. 1948;22:93-105.

11. Chen YZ, Xu XL, Chen BJ, Guo ZF, Zhen HY, Lin SS, et al. First report on human infection of Centrocestus formosanus (in Fujian). Chin J Parasitol Parasit Dis. $1991 ; 9: 273$

12. Fernandez MA, Thiengo SC, Simone LRL. Distribution of the introduced freshwater snail Melanoides tuberculatus (Gastropoda: Thiaridae) in Brazil. Nautilus. 2003;117:78-82

13. Freitas JR, Santos MBL. Current advances on the study of snail-snail interactions, with special emphasis on competition process. Mem Inst Oswaldo Cruz. 1995;90:261-9.

14. Giovanelli A, Silva CLPAC, Leal GBE, Baptista DF. Habitat preference of freshwater snails in relation to environmental factors and the presence of the competitor snail Melanoides tuberculatus (Müller, 1774). Mem Inst Oswaldo Cruz. 2005;100:169-76.

15. Gjurčević E, Petrinec Z, Kozaric Z, Kužir S, Gjurcevic Kantura V, Vučemilo M, et al. Metacercariae of Centrocestus formosanus in goldfish (Carassius auratus L.) imported into Croatia. Helminthologia. 2007;44:214-6.

16. Godinho HP, Santos GB, Alves CBM, Formagio PS. Os peixes e a pesca na represa da Pampulha. In: Anais do Seminário sobre a Bacia Hidrográfica da Pampulha.. Belo Horizonte; Segrac; 1992. p. 86-97.

17. Han ET, Shin EH, Phommakorn S, Sengvilaykham B, Kim JL, Rim HJ, et al Centrocestus formosanus (Digenea: Heterophyidae) encysted in the freshwater fish, Puntius brevis, from Lao PDR. Korean J Parasitol. 2008;46:49-53.

18. Hernandez LE, Díaz MT, Bashirullah A. Description of different developmental stages of Centrocestus formosanus (Nishigori, 1924) (Digenea: Heterophyidae). Rev Cient. 2003;13:285-92.

19. Hong SJ, Seo BS, Lee SH, Chai JYA. A human case of Centrocestus armatus infection in Korea. Korean J Parasitol. 1988;26:55-60.

20. Komiya Y, Suzuki N. The metacercariae of trematodes belonging to the family Heterophyidae from Japan and adjacent countries. Jpn J Parasitol. 1966;15:208-14.

21. Kurokawa T. On a new trematode of genus Stamnosoma proved from a man. Tokyo Iji Shinji. 1935;2915:293-8.

22. Martin WE. The life histories of some Hawaiian heterophyid trematodes. J Parasitol 1958;44:305-23 
PINTO, H.A. \& MELO, A.L. - Melanoides tuberculata (Mollusca: Thiaridae) as an intermediate host of Centrocestus formosanus (Trematoda: Heterophyidae) in Brazil. Rev. Inst. Med. Trop. Sao Paulo, 52(4): 207-10, 2010.

23. Melo AL. Caracterização de larvas de trematódeos emergentes de moluscos dulciaquícolas. In: Amaral RS, Thiengo SC, Pieri OS, organizadores. Vigilância e controle de moluscos de importância epidemiológica: diretrizes técnicas: Programa de Vigilância e Controle da Esquistossomose (PCE). 2 ed. Brasília: Editora do Ministério da Saúde; 2008. p. 71-80.

24. Mitchell AJ, Goodwin AE, Salmon MJ, Brandt TM. Experimental infection of an exotic heterophyid trematode, Centrocestus formosanus, in four aquaculture fishes. N Am J Aquacult. 2002;64:55-9.

25. Mitchell AJ, Overstreet RM, Goodwin AE, Brandt TM. Spread of an exotic fish-gill trematode: a far-reaching and complex problem. Fisheries. 2005;30:11-6.

26. Mitchell AJ, Salmon MJ, Huffman DG, Goodwin AE, Brandt TM. Prevalence and pathogenicity of a heterophyid trematode infecting the gills of an endangered fish, the Fountain Darter, in two central Texas spring-fed rivers. J Aquat Anim Health. $2000 ; 12: 283-9$

27. Nath D. Experimental development of Centrocestus formosanus (Nishigori, 1924) in Indian domestic poultry with notes on natural infection. Indian J Anim Sci. $1972 ; 42: 862-8$

28. Nguyen TL, Nguyen TP, Johansen MV, Murrell KD, Phan TV, Dalsgaard A. et al. Prevalence and risks for fishborne zoonotic trematode infections in domestic animals in a highly endemic area of North Vietnam. Acta Trop. 2009;112:198-203.

29 Nishigori M. On a new species of fluke, Stamnosoma formosanum, and its life history. Taiwan Igakkai Zasshi. 1924;234:181-238.

30. Ortega C, Fajardo R, Enríquez R. Trematode Centrocestus formosanus infection and distribution in ornamental fishes in Mexico. J Aquat Anim Health. 2009;21:18-22.

31. Pellegrino J, Macedo DG. A simplified method for the concentration of cercariae. J Parasitol. 1995;41:329-33.

32. Pérez-Ponce de Leon G, Garcia-Prieto L, Mendoza-Garfias B. Trematode parasites (Platyhelminthes) of wildlife vertebrates in Mexico. Zootaxa. 2007;1534:1-247.

33. Pimenta FE, Drummond JCP, Lima AC. Aves aquáticas da Lagoa da Pampulha: seleção de hábitats e atividade diurna. Lundiana. 2007;8:89-96.

34. Premvati G, Pande V. On Centrocestus formosanus (Nishigori, 1924) Price, 1932 and its experimental infection in white leghorn chicks. Jpn J Parasitol. 1974;23:79-84.
35. Salgado-Maldonado G, Rodriguez-Vargas MI, Campos-Perez JJ. Metacercariae of Centrocestus formosanus (Nishigori, 1924) (Trematoda) in freshwater fishes in Mexico and their transmission by the thiarid snail Melanoides tuberculata. Stud Neotrop Fauna Environ. 1995;30:245-50.

36. Scholz T, Salgado-Maldonado G. The introduced and dispersal of Centrocestus formosanus (Nishigori, 1924) (Digenea: Heterophyidae) in México: a review. Am Midl Nat. 2000;143:185-200

37. Simões SBE, Santos CP, Barbosa HS. Centrocestus formosanus (Trematoda Heterophyidae) em Poecilia vivipara (Osteichthyes) da Lagoa Rodrigo de Freitas, RJ, Brasil. In: Anais do XIV Congresso Brasileiro de Parasitologia Veterinária \& II Congresso Latino-Americano de Rickettsioses, Ribeirão Preto; 2006. p. 299.

38. Srisawangwong T, Pinlaor S, Kanla P, Sithithaworn P. Centrocestus formosanus: surface morphology of metacercaria, adult and eggs. J Helminthol. 1997; 71:345-50.

39. Thiengo SC, Fernandez MA, Boaventura MF, Grault CE, Silva HF, Mattos AC et al Freshwater snails and schistosomiasis mansoni in the state of Rio de Janeiro, Brazil: I - Metropolitan mesoregion. Mem Inst Oswaldo Cruz. 2001;96(Suppl. 1):177-84.

40. Vaz JF, Teles HMS, Correa MA, Leite SPS. Ocorrência no Brasil de Thiara (Melanoides) tuberculata (O.F. Müller, 1774) (Gastropoda, Prosobranchia), primeiro hospedeiro intermediário de Clonorchis sinensis. Rev Saúde Pública. 1986;20:318-22.

41. Velásquez LE, Bedoya JC, Areiza A, Vélez I. Primer registro de Centrocestus formosanus (Digenea: Heterophyidae) en Colombia. Rev Mex Biodiv. 2006;77:11921.

42. Velez-Hernandez EM, Constantino-Casas F, Garcia-Marquez LJ, Osorio-Sarabia D Gill lesions in common carp, Cyprinus carpio L., in Mexico due to the metacercariae of Centrocestus formosanus. J Fish Dis. 1998; 21:229-32.

43. Vergara D, Velasquez LE. Larval stages of Digenea from Melanoides tuberculata (Gastropoda: Thiaridae) in Medellín, Colombia. Acta Biol Colomb. 2009;14:135-42.

44. Yu S, Xu L, Jiang Z, Xu S, Han J, Zhu Y et al. Report on the first nationwide survey of the distribution of human parasites in China. 1. Regional distribution of parasite species. Chin J Parasitol Parasit Dis. 1994;12:241-7.

Received: 22 February 2010

Accepted: 1 June 2010 